\title{
Recessions in a Two-Sector Model: Capitalists' Risk Preferences Determine Workers' Real Wages
}

\author{
二部門モデルを用いた景気理論： 資本家のリスク選好度が労働者の実質貨金を規定する
}

\author{
Yuuki Maruyama
}

\begin{abstract}
With a two-sector model of the consumer goods sector and the capital goods sector, this paper analyzes workers' real wages. The higher the risk preference of capitalists, the greater the ratio of capital goods to safe assets in savings, the labor demand in the capital goods sector will increase, some workers will move from the consumer goods sector to the capital goods sector, the marginal product of labor will rise in both sectors, and workers' real wages will increase. In this model, a sudden increase in capitalists' risk aversion can cause a recession. In addition, this model is used to analyze monetary policy, suppression of an overheating economy, and two positive externalities from capitalists to workers.
\end{abstract} (JEL Classification: E13, E24, E25, E32, E40, E44, E50, J23)

消費財部門と資本財部門との二部門モデルを用いて、労働者の実質賃金の規定要因につい て分析を行う。資本家のリスク回避度が低ければ低いほど、安全資産よりも資本で貯蓄が行 われるようになり、資本財部門における労働需要が上昇し、消費財部門と資本財部門とに労 働者が分散するようになり、労働の限界生産性が増加し、労働者の実質賃金が増加する、と いう結論が示される。資本家のリスク回避度の増加が景気後退を起こしうることが分かる。 またこのモデルを用いて、金融政策、景気過熱の抑制、資本家から労働者に対する 2 種類の 外部性、などについても分析する。

\section{1 序論}

既存の経済学のモデルにおいては、貯蓄は全て投資されるとするモデルが多い。しかし、 設備投資や事業投資というのはリスクを伴うものであり、貯蓄額の全てが投資されるとい うのは現実の経済においては考えにくい。銀行や株式などの金融システムを介してではあ るが、貯蓄額の一部が設備投資のための資本財の購入に充てられ、貯蓄額のうちの残りは 「価值の保存機能」を有する安全資産（貨幣など）として保管されるという想定が自然であ 
る。

今回は、Merton(1971) などに基づき、リスク回避度に応じて貯蓄額のうちのどのくらい が資本財の購入に使われるかが定まるモデルを考える。モデルは消費財と資本財の二部門 モデルであり、実体経済モデルとする。このモデルの分析により、資本家のリスク回避度が 低いほど、資本家の貯蓄の内の資本財の割合が高くなり、資本財部門における労働需要が上 昇し、消費財部門と資本財部門とに労働者が分散するようになり、労働の限界生産性が増加 し、労働者の実質賃金が増加する、という結論が得られる。資本家のリスク回避度が労働者 の実質賃金に対して外部経済性を持つということである。

また、今回はこれを景気の分析に対しても用いる。不景気は、資本家のリスク回避度の急 増が原因となり実体経済的なメカニズムに基づいて発生するものであるというモデルを提 示する。実際、世界恐慌においては設備投資が大きく減少したとされている。株価の暴落な どにより同時多発的に資本家のリスク回避度が高まり、設備投資が減少し、労働者の実質債 金が低下した（もしくは実質賃金の低下の代わりに失業が増加した）可能性が考えられる。

さらに、今回のモデルを用いて、金融政策、フィリップス曲線、景気過熱の抑制、資本家 から労働者に対する二種類の外部性、などについても分析する。

\section{2 モデル}

\section{1 モデルの設定}

このモデルでは消費財部門と資本財部門との二部門が存在する。資本財部門は労働力の みを用いて生産を行い、消費財部門は資本と労働力の両者を用いて生産を行う。労働力の産 業間移動はスムーズであり、両部門の実質賃金に差が生まれると労働者はすぐに移動する とする。価格も全て伸縮的であり、市場は完全競争市場とする。人々は労働者と資本家の 2 つに分けられるとし、労働者は貯蓄を行わず各期での所得を全て消費するとする。資本家は 各期の所得のうち、一部を消費し、残りを貯蓄する。貯蓄は、貨幣として保持する分と資本 財の購入をする分とに分けられる。資本財の購入によって投資を行う場合はリスクが存在 するが、貨幣の保持にはリスクは伴わないものとする。資本家のリスク回避度を定義するた めにのみ、CRRA 型効用関数を利用する。

このモデルにおいては、各変数の次元を明記しておく。消費財は「個」、資本財は「単位」、 労働力は「人」（無次元としても扱える）、貨幣は「円」、で数える。

$\cdot y$ : 資本財部門の生産量 [単位 $]$

$\cdot Y:$ 消費財部門の生産量 [個 $]$

・ $K$ : 消費財部門に使われている資本の量 $[$ 単位 $] \quad （$ 短期的には定数） 
$\cdot n:$ 資本財部門の労働者数 $[人]$

$\cdot N$ : 消費財部門の労働者数 [人]

$\cdot L:$ 国の労働者の人口 [人]

・ $\beta$ : 消費財部門のコブダグラス型生産関数の労働分配率 [(無次元) $]$

$\cdot a$ : 資本財部門の生産関数における定数 [単位 / 人]

$\cdot A$ : 消費財部門の生産関数における定数 $\left[\right.$ 個 / 人 $^{\beta} /$ 単位 $\left.^{1-\beta}\right]$

$\cdot S:$ 資本家の貯蓄のストック $[$ 円]

- $R$ : 資本家の今期の所得の期待值 [個 $]$

$\cdot s$ : 資本家の貯蓄性向 $[($ 無次元 $)] \quad(s>0$ とする $)$

- $\gamma$ : 資本家のリスク回避度（CRRA 型効用関数に基づく） [(無次元 $)]$

$\cdot q:$ 資本家の貯蓄に占める資本財の割合 [(無次元 $)]$

・ I : 資本家の今期の投資額 [個 $]$

$\cdot r:$ 投資の利子率の期待值 $[$ (無次元 $)]$

$\cdot \sigma:$ 投資の利子率の標準偏差 $[$ (無次元 $)]$

・ $w$ : 実質賃金（消費財の量で表された貨金）[個 / 人］

- $P$ : 消費財物価 $[$ 円 / 個 $]$ (今回は定数として扱う。詳しくは後述)

$\cdot M$ : 流通貨幣量 $[$ 円 $]$

・r [ 無次元 $]$ は $\frac{\partial Y}{\partial K}$ [個 / 単位 $]$ とは異なることに注意が必要である。また、 $w$ は実質貨 金であることに注意。

・文字の右下についている数字は時間を表す。例えば $\gamma_{0}$ であれば、第 0 期の $\gamma$ の值を表す。

・このモデルにおいて投資は、一度資本財を購入して投資すると以後毎期ごとに配当がもら えるという株式の方式で行われるものとする。債券の方式のように資本財の額の元本が戻 ってくることはない。

・資本の減価償却は考えない

・資本は取り崩せないものとする（つまり、I $I \geq 0$ でなければならず、 $K_{t}$ は $t$ について単調 増加とならなければならならない)

・今回は $K \gg \Delta K$ と仮定することで、短期的には $K$ は定数であるとし、資本の増加は $r$ の值 に影響を与えないものとする。

・貨幣量は一定であるとし、中央銀行による貨幣供給は行われないものとする。

・貨幣に取引需要は存在せず、貯蓄のための需要のみが存在する。

・消費財部門の労働者や資本家は所得を消費財の形で受け取り、資本財部門の労働者は所得 を資本財の形で受け取るとする。

・資本家は、消費財部門からの配当で収入を得る。そして、資本財が欲しい時は、資本財産 
業の労働者に消費財を渡し、資本財を受け取る。貨幣が欲しい時は、他の資本家に消費財を 渡し、貨幣を受け取る。消費財がさらに欲しい時は、他の資本家に貨幣を渡し、消費財を受 け取る。

\section{2 均衡分析}

資本財部門の生産関数 $y$ と消費財部門の生産関数 $Y$ はそれぞれ、

$$
\begin{aligned}
& \mathrm{y}=a n \\
& Y=A K^{1-\beta} N^{\beta}
\end{aligned}
$$

労働者の人数は一定であるため、 $n+N=L$

労働者の産業間移動は摩擦なく行うことができるため、両産業の実質賃金は等しくなる。実 質賃金を消費財産業の生産関数から求めると、

$$
w=\frac{\beta Y}{N}=\frac{\beta A K^{1-\beta}}{N^{1-\beta}}
$$

短期的には $K$ は定数とみなせるため、 $w$ は $N$ の一変数関数といえる。

資本家全体の所得は $R=(1-\beta) Y=(1-\beta) A K^{1-\beta} N^{\beta}$

投資については、今期で $w n P[$ 円] を投資すると、今後毎期ごとにもらえる配当額の期待值 は $\frac{(1-\beta) Y}{K} \times a n \times P[円]$ であるため、 $r=\frac{(1-\beta) a N}{\beta K}$ となる。ただし、消費財部門の生産量に は不確定性があるとし、そのリスクは全て資本家が負担するものとする。このため、 $r$ につ いては分散 $\sigma^{2}$ の不確定性があるとする。

資本家は貯蓄を安全資産の貨幣とリスク資産の資本のいずれかで持つが、リスク回避度が $\gamma$ であるため、リスク資産の割合は $q=\frac{r}{\sigma^{2} \gamma}=\frac{(1-\beta) a N}{\beta K \sigma^{2} \gamma}$ となる(詳細は Merton(1971)などを参 照)。 $x=\frac{(1-s) \beta K \sigma^{2} \gamma}{(1-\beta) a}$ とすると、 $\frac{1-s}{q}=\frac{x}{N}$ と表せる。

形としては、資本家は、消費 : 貨幣による貯蓄 : 投資を、 $1-s:(1-q) s: q s$ の比率で行 うことになる。しかし、貨幣の総量は一定であるため、資本家集団全体として見れば、貨幣 による貯蓄を本質的な意味では行うことはできない。そのため、代わりに貨幣の価值が増価 することになる（資本家同士で消費財と貨幣を交換するための市場における貨幣の相対価 格が増加する)。 $\Delta \frac{1}{P}$ 変化した場合、 $M \Delta \frac{1}{P}$ の分だけ貨幣貯蓄がなされたことになる。また、 資本家は消費財の形で収入を得るわけであるが、その消費財は、消費としての利用と資本財 の購入のための利用との二つに分けられ、両者の和が $(1-\beta) Y$ となる。

資本家同士で消費財と貨幣を交換するための市場における均衡を考えると、資本家は、消費 を $\frac{(1-s)(1-\beta) Y}{1-s+q s}$ 、貨幣による貯蓄を $\frac{(1-q) s(1-\beta) Y}{1-s+q s}$ 、投資を $\frac{q s(1-\beta) Y}{1-s+q s}$ だけ行うことになり、また、 
$M \Delta \frac{1}{P}=\frac{(1-q) s(1-\beta) Y}{1-s+q s}$ となる。また今回は、M が十分に大きいと仮定することによって、

$\Delta \frac{1}{P} \fallingdotseq 0$ とみなせることにする。 $P$ が変動することにしてしまうと、インフレ率 (安全資産の 減価率) $\pi$ を考えることが必要になり、 $q=\frac{r+\pi}{\sigma^{2} \gamma}$ となって分析が複雑になるためである。 $P$ は定数として扱う。

（貨幣による貯蓄については Di Tella (2018)などが詳しい)

この節では、資本家のリスク回避度 $\gamma$ が長期的に安定しているとして分析し、均衡状態 における $N, w$ を求める。

資本財部門の労働者全体の収入と資本家の投資額とは等しいため、

$$
\begin{aligned}
w n & =I \\
& =\frac{q s(1-\beta) Y}{1-s+q s} \\
& =\frac{s(1-\beta) Y}{\frac{1-s}{q}+s}
\end{aligned}
$$

この $w, n, \frac{1-s}{q}$ にこれまで求めた式を代入すると、

$$
\frac{\beta Y}{N}(L-N)=\frac{s(1-\beta) Y}{\frac{x}{N}+s}
$$

となる。これを整理すると、

$$
s N^{2}+\beta(x-s L) N-\beta L x=0
$$

という $N$ の二次方程式が得られる。

$s, \beta, L, x>0$ なので、 $N$ は正の解と負の解を一つずつ持つ。 $N>0$ より、

$$
N=\frac{-\beta(x-s L)+\sqrt{\beta^{2}(x-s L)^{2}+4 \beta s L x}}{2 s}
$$

$x>0$ より $\frac{\partial N}{\partial x}>0$ となり、 $N$ は $x$ についての単調増加関数となる。また、 $\beta L<N<L$ とな るため、 $N$ の定義にも合致する。 $w$ については、この $N$ の值を $w=\frac{\beta A K^{1-\beta}}{N^{1-\beta}}$ に代入すること で求められる。

故に、 $\gamma$ が大きいほど、 $x$ は大きくなり、 $N$ は大きくなり、 $w$ は小さくなる。 $w$ は $\gamma$ の単 調減少関数となっている。つまり、資本家のリスク回避度が高いほじ、労働者の実質賃金は 
低くなることが示された。

このモデルで示された資本家のリスク回避度と労働者の実質賃金との関係性についての メカニズムは以下の通りである。資本家のリスク回避度が高いほじ、資本家は貯蓄を資本財 ではなく貨幣で行うようになり、資本財の需要が減少し、資本財部門の労働需要も減少する。 すると、両部門に分散していた労働者が消費財部門のみに集まってしまうようになり、労働 力の限界生産性が低下し、労働者の実質賃金も低下寸る、という原理である。資本家のリス ク回避度の高さにより労働者の実質債金が外部不経済効果を受けているといえる。

また、今回のモデルでは、 $\gamma$ の高さによる $w$ の低下に対してブレーキの効果も内在してい ることに注意が必要である。 $\gamma$ が高いほど、消費財部門に労働者が集まる分、資本の限界生 産性が高まり $r$ や $R$ は高くなるため、投資量の低下に対して抑制がかかっている。ただし、 その効果は十分に強くはないために、 $w$ は $\gamma$ の単調減少関数となっている。

\section{3 景気変動}

次に、資本家のリスク回避度 $\gamma$ が長期的に安定しているという仮定を取り除く。この場 合は、資本家の投資量は $I=\frac{q_{1} s(1-\beta) Y_{0}}{1-s+q_{1} s}+\frac{(1-s)\left(q_{1}-q_{0}\right) S_{0}}{\left(1-s+q_{1} s\right) P}$ となり、先程と比べ第二項が加わる。 突然、資本家のリスク回避度が $\gamma_{0}$ から $\gamma_{1}$ へと増加するとする。 $I$ は $I \geq 0$ という制約がある ため、 $\frac{q_{1} s(1-\beta) Y_{0}}{1-s+q_{1} s}+\frac{(1-s)\left(q_{1}-q_{0}\right) S_{0}}{\left(1-s+q_{1} s\right) P}<0$ の場合、つまり

$$
\frac{\gamma_{1}}{\gamma_{0}}>1+\frac{s(1-\beta) A K^{1-\beta} N_{0}^{\beta} P}{(1-s) S_{0}}
$$

となるほどに $\gamma_{1}$ が高いときは、 $I=0$ となりその期の投資は全く行われなくなる。よってこ の場合、労働者の実質貨金 $w$ は、 $\frac{\beta A K^{1-\beta}}{N_{0}{ }^{1-\beta}}$ から $\frac{\beta A K^{1-\beta}}{L^{1-\beta}}$ へと減少することになる。また、

$\frac{q_{1} s(1-\beta) Y_{0}}{1-s+q_{1} s}+\frac{(1-s)\left(q_{1}-q_{0}\right) S_{0}}{\left(1-s+q_{1} s\right) P} \geq 0$ の場合については代数的には解けないため今回は数式による分 析を控えるが、この場合も実質賃金は低下寸る。資本家のリスク回避度が長期的に安定して いるとする先ほどのモデルにおいて $\gamma=\gamma_{1}$ を代入する場合と比較しても、実質貨金はそれ よりさらに低くなる。というのも、 $I=\frac{q_{1} s(1-\beta) Y_{0}}{1-s+q_{1} s}+\frac{(1-s)\left(q_{1}-q_{0}\right) S_{0}}{\left(1-s+q_{1} s\right) P}$ の第二項が負になるせいで ある。以上より、資本家のリスク回避度の急増により、実体経済的な不景気が生じうること が示された。

資本家のリスク回避度の増加による $w$ の低下は、実質賃金の低下という形で起こっても 
よいし、失業率の上昇という形で起こってもよい。実質賃金に下方硬直性がなければ、実質 賃金の低下という形で起こるだろうし、下方硬直性があれば失業率の上昇という形で現れ るであろう。どちらにせよ $w$ が低下することには変わりない。

\section{4 中央銀行、労働の産業間移動、2 種類の外部性 など}

また今回は、中央銀行が存在せず、貨幣量は一定であり、消費財物価は常に一定、という 仮定を置いたが、中央銀行が貨幣量を操作することができると仮定することも可能である。 例えばインフレ率を一定に保つような水準でヘリコプターマネーによって貨幣供給すると いう設定を考える。この場合、安全資産の貨幣で貯蓄すると次第に減価していくことになる ため、インフレ率を $\pi$ とすると、リスク資産と安全資産それぞれで貯蓄を行った場合の収益 率の差の期待值は $r+\pi$ となる。よって $q=\frac{r+\pi}{\sigma^{2} \gamma}$ となり、 $\pi$ が大きいほど $w$ は高くなる（ $\pi$ の上昇により $w$ が増加することになり、これはフィリップス曲線に該当する)。また、中央 銀行が公開市場操作として買いオペレーションを行い、新規発行貨幣で資本家から資本を 購入すると想定することも可能である。資本の買いオペレーションにより、資本家の貯蓄に 占める資本の割合が $q$ を下回ることになるので、資本家はその分新たに投資を行うことで 資本の割合を $q$ まで戻すことになる。この場合、資本の買いオペレーションの量を $Q[$ 円 $]$ とすると、 $I=\frac{q s(1-\beta) Y}{1-s+q s}+\frac{Q}{P}$ となり、 $w$ は増加する。このようにインフレ率を上げる方法と資 本を購入する方法の両者とも景気を上昇させることは可能である。ただ、どちらもリスクは 伴う。一度、貨幣への信頼が失われると、人々は別の物（例えば金など）で貯蓄をするよう になり、貨幣が安全資産としては用いられなくなってしまう。この場合、貨幣需要は消失す ることになるため、中央銀行は景気操作能力を失い、さらにハイパーインフレーションも起 こると考えられる。(加えて、 $q=\frac{r}{\sigma^{2} \gamma}$ に戻る)

今回のモデルにおいては労㗢の産業間移動がスムーズであるという仮定を置いて分析し たが、もし労働の産業間移動がスムーズでない場合は $w L$ の低下（失業率の上昇）はさらに 深刻となる。本来、資本家のリスク回避度が上がる場合、資本財部門で働いていた労働者は スムーズに消費財部門へと移動しなければならない。しかし、労働の産業間移動がスムーズ でなければそれが起こらず、その分の労働者が失業者となってしまう。よって、もともと資 本財産業で働いていた労働者の人数 $n_{0}$ が多いほど失業者は多く発生するということになる。 つまり、 $\gamma_{1}$ が同じなら、 $n_{0}$ が高い場合ほど失業率は大きくなる。そのため、労働の産業間 移動がスムーズでない場合においては、投資ブームなどにより $\gamma$ が急減して平均回帰值か ら乘離するような時にも資本財部門に労働者が移動しすぎないように、政府や中央銀行は こまめに景気の過熱を抑制する（いわば $n_{0}$ を適正な值に保っておく）ことが大切であると 
考えられる。

また、今回のモデルにおいては、 $K \gg \Delta K$ とし、投資による資本の増加が消費財部門に与 える影響を無視できるとしたが、実際は $K$ の増加により消費財部門における労働の生産性 が増加することになる。つまり投資から労働への外部性は、短期的に見れば資本財部門に雇 用を作り出すことであり、長期的に見ればそれに加えて、消費財部門の労働の生産性を上昇 させる効果もある。長期的には、投資は労働者に対して二重の外部経済性をもたらすという ことである。おおまかには、前者の短期的外部性は景気理論において重要であり、後者の長 期的外部性は経済成長理論において重要であると言える。

また、本モデルにおいては(3)の不等式が成り立つ場合は投資がゼロになってしまうとい う結果が出た。しかし、これは非現実的であろう。今回のモデルにおいては全ての投資案件 は利子率の平均が $r$ 、分散が $\sigma^{2}$ であると仮定してしまったが、現実の経済においては各投資 案件についてこれらの值は様々であると考えられる。不景気の際にもリスクプレミアムの 高い投資案件については実行され、投資量はゼロにはならないと思われる。

最後に、今回のモデルは閉鎖経済のモデルであることに注意が必要である。開放経済であ れば、資本の流入や流出が発生するため、今回の分析は成り立たない。

\section{3 結論}

今回のモデルを通して、

・資本家のリスク回避度が高いほど、労働者の実質賃金は低くなる

・資本家のリスク回避度の急な増加により、労働者の実質賃金は減少する（不景気）

・中央銀行はインフレ率操作や資本の買いオペレーションを通じて景気悪化を緩和できる

・インフレ率の上昇により、労働者の実質賃金は増加する（フィリップス曲線）

・労働者の産業間移動がスムーズでない場合は、景気過熱抑制政策の重要性が高い

・長期的に見れば労働者に対する資本家の外部経済性として、資本財部門に労働需要を作り 出すこと、消費財部門の労働の生産性を上昇させること、の 2 つが存在する

などの事項について述べた。実際の経済のデータにおいてこれらの事柄がどの程度成立す るのかについての実証研究が今後の課題である。 


\section{参考文献}

Di Tella, S. (2018). A Neoclassical Theory of Liquidity Traps. NBER Working Paper, (w24205).

Judd, K. L. (1985). Redistributive taxation in a simple perfect foresight model. Journal of public Economics, 28(1), 59-83.

Merton, R. (1971). Optimum consumption and portfolio rules in a continuous-time model. Journal of Economic Theory, 3(4), 373-413.

Srinivasan, T. N. (1964). Optimal savings in a two-sector model of growth. Econometrica: Journal of the Econometric Society, 358-373.

Uzawa, H. (1964). Optimal growth in a two-sector model of capital accumulation. The Review of Economic Studies, 31(1), 1-24. 